Tények és vélemények a kritikai geográfiáról , a 3. Nemzetközi Kritikai Geográfiai Konferenciáról

Tér és Társadalom 17. évf. 2003/2. 107-110. p.

TÉT XVII. évf. 2003 @ 2

Tények és vélemények a kritikai geográfiáról

107

\title{
A TERMÉSZET GEOGRÁFIÁI
}

\author{
(Geographies of Nature)
}

\section{CAROLINE DESBIENS}

A Békéscsabán megrendezett 3. Nemzetközi Kritikai Geográfiai Konferencia nyolc témája közül az egyiket, a „Természet geográfiái” címüt Neil Smith-szel együtt koordináltuk. Az e témában tartott szekciók fö célja annak kritikai megértése volt, hogyan válik a természet a különféle társadalmi, kulturális és politikai geográfiák részévé; ehhez föleg a politikai ỏkológia, környezeti igazságosság, valamint a természet és társadalom marxista megközelítése szolgált segítségül. A témában négy különböző panelvita foglalkozott a következö kérdésekkel:

1) „A természet a politikai geográfia keresztútján”, elnök: Koji Nakashima.

2) „A környezetgazdálkodás kritikai perspektívái”, elnök: Heath Priston.

3) „A környezeti veszélyek és degradáció kritikai perspektívái”, elnök: Kenji Tsutsumi.

4) „Természet, faj, identitás”, elnök: Caroline Desbiens.

A résztvevők elöre megkapták a tanulmányokat, hogy rövidre fogjuk az elóadásokat, és több időt hagyjunk a vitára. A panelviták munkája kerekasztal-beszélgetéssel zárult, melynek címe „Társadalomelméletek és ökológiai kérdések” volt. A megbeszélés kiinduló pontja Andrea Nightingale dolgozata volt, amelyben a szerző a következő kérdéseket tette fel: „Megfelelően tudja-e a társadalomelmélet kezelni a természet-társadalom [kapcsolat] problémáit?” és „A politikai ökológia és az egyetemi geográfiai stúdiumok magukban foglalják-e az ökológiai változásokat?" SangHun Lee, Caroline Desbiens, Bruce Braun és Neil Smith külön-külön hivatalosan reagáltak a tanulmányra; utána a vita következett. Ebben a záró kerekasztalszekcióban több olyan kérdés és probléma is felvetödött, amelyet a panelviták során elözőleg már megtárgyaltak. Az alábbiakban a központi problémákat részletezem.

A „,Környezetgazdálkodás kritikai perspektívái” témában a résztvevők ráirányították a figyelmet az olyan környezetgazdálkodási keretek kialakításának nehézségeire, amelyek el tudják kerülni a természet és társadalom közötti, a modern kultúrákat annyira átható episztemológiai megosztottságot. A radikális zöld politika koncepcióit, az alkalmazkodást és az együttmüködést mint a természet, természeti erőforrások, a társadalom és fejlődés közötti dialektikus kapcsolat újrafogalmazásának lehetséges módjait tárták fel. Minden elöadásból az derült ki, hogy új episztemológiai keretekre van szükség, hogy a tisztán ,gazdálkodási” megközelítéseket túl lehessen lépni, olyan folyamatra, amely magával a „gazdálkodás” szó kritikai alkalmazásával kezdődhetne, s azokkal a gyakorlatokkal, amelyeket előidéz. Matt Szabo úgy érvelt, hogy a modernitásban a „környezetet” a maximális gazdálkodási hatékonyság kívánalmai szerint „szelídítették meg”. Nick Garside pedig a természet átpoliti- 
Tények és vélemények a kritikai geográfiáról , a 3. Nemzetközi Kritikai Geográfiai Konferenciáról Tér és Társadalom 17. évf. 2003/2. 107-110. p.

108 Tények és vélemények a kritikai geográfiáról

TÉT XVII. évf. 2003 — 2

zálásáról mint az alkalmazás eme eltérỏ formája feltérképezésének mikéntjéröl beszélt. E panel második részében Dean Bavington bemutatta a „küzdelem” és „irányítás” bonyolult voltát, amely - nevezetesen Heath Priston és Saeed Parto részéröl - a környezetpolitika problémáinak elhúzódó megtárgyalásához vezetett. „A környezeti veszélyek és degradáció kritikai perspektívái”-val foglalkozó kisebb panelvita bekapcsolódott ezeknek a problémáknak a megtárgyalásába: megvizsgálta a környezeti leépülés társadalmi és politikai okait és a róla alkotott véleményeket. A japán és magyar esettanulmányok bemutatták az egymással versengỏ diskurzusok veszélyekre és degradációra gyakorolt hatását, miközben meghatározták azokat a tennivalókat, amelyek az ilyen helyzetekbe való pozitív beavatkozáshoz szükségesek.

„A természet a politikai geográfia keresztútján” panelban a résztvevők a természet és a kulturális termelés, föleg a nemzeti identitások kiépítése közötti keresztutat mutatták be. Naoki Oshiro és Iria Matsuda a japán táj „eltermészetietlenítéséről” beszélt, ami a helyi identitásokat fenntartó folyamat. Maano Ramutsindela és Koji Nakashima a szuverenitás és az ellenállás problematikáját mutatta be a természet kisajátításán keresztül Dél-Afrika, valamint a japán Hijudai kontextusában, míg Marcella Schmidt a részvétel és környezeti konfliktusok összetettségét Olaszországban vizsgálta. Ugyancsak a „természet/nemzet” kapcsolatok kategóriájában egy másik panel a „Természet, faj és identitás” témakörben a természethez füződő érzelmi kapcsolatok különféle formáit tárgyalta a nemzeti parkok, az erdőségek és a városi környezetek vizsgálata segítségével. Mindkét panelvitában minden előadás egy-egy példával szolgált arra, hogyan ágyazódnak be mindig a természettel és a környezettel kapcsolatos viták egy-egy konkrét kulturális és nemzeti kontextusba. Az előadásokat követő vita e beágyazódás tanulmányozásának - mint a természet és a társadalom kapcsolatairól szóló elemzéseink „lehorgonyzása” egyik eszközének - fontosságát hangsúlyozta. Bár ezt az elemzést gyakran végzik konkrét hivatkozási keret nélkül, a panelban megtárgyalt dolgozatok a természet körüli kulturális kontúrok megrajzolásával szorították sarokba az elvont elméletieskedést. Mindegyik esettanulmány más és más tudás-, perspektíva- és elváráskészlettel utalt a természetre, mivel arra más és más kulturális, politikai és gazdasági cél érdekében volt szükség.

A záró kerekasztal-beszélgetés a fenti problémák közül többet is érintett, és reagált Andrea Nightingale "helyzetbe hozó tanulmányára". Ebben azt a kérdést tette fel, hogy azok a kritikai geográfusok (és politikai ökológusok), akik felhívják a figyelmet a természet társadalmi felépítésére, miért csak ritkán használnak ökológiai adatokat elemzéseikben. Azzal érvelt, hogy amikor megkísérlik bevonni ezeket az adatokat, a társadalomföldrajzosok gyakran fordulnak Bruno Latour munkáihoz, amelyek a természet és a társadalom közötti érintkezési felületet elemzik a „szereplö-hálózat" elméletének (ANT) és az elméletnek az ökológiai faktorokról mint „termékekröl" alkotott elképzelésének a segítségével. Nightingale azt a kérdést tette fel, hogy az ilyen, a természetre, mint „termékre” irányuló figyelem elvon-e bennünket az ökológiai változás megértésétöl, amely egyszerre társadalmi és természeti. Hogyan tarthatják szem elött munkájukban a kritikai geográfusok ezt a feszültsé- 
Tények és vélemények a kritikai geográfiáról , a 3. Nemzetközi Kritikai Geográfiai Konferenciáról Tér és Társadalom 17. évf. 2003/2. 107-110. p.

TÉT XVII. évf. 2003 - Tények és vélemények a kritikai geográfiáról

get, s miről maradunk le, amikor szem elöl veszítjük azt? Az ezt követö vitában a hallgatóság és az elöadók a kultúra és az ökológia ugyanazon analitikai keretbe történő bevonásának fontosságát hangsúlyozták, és kijelentették, hogy a kulturális gyakorlatoknak ökológiai hasznuk van, és fordítva. Latour „kvázi-tárgy” koncepciójára összpontosítva a figyelmet, Bruce Braun azt a megállapítást tette, hogy a modernitás eredményeként ,a társadalom az ökológiába omlott”, s azzal érvelt, hogy Latour inkább a kapcsolatok és kicserélődések rivális ontológiáját nyújtja, mint megtisztulást. Jobban érdekli a közvetítés és a kicserélődés, mint amennyire a tárgyak, amint ezt a darázsról és az orchideáról szóló elképzelése példázza: az egyik mindig a másikká válik közös kölcsönhatásuk révén. Ezek a közvetítő folyamatok (vagy „kvázi-tárgyak”) elvesznek, amikor merev kontúrokat húzunk a természet köré, vagy amikor tárgyként közelítjük meg.

Neil Smith - a tanulmányra adott válaszában - a hálózatok felépítésének szélesebb körü megértésére ösztönzött, és megemlítette, nem feltételezhetjük, hogy minden társadalmilag konstruált. Felvetette azt a problémát, hogy a természet társadalmi felépítésének látásmódja eléggé beszúkült, s azzal érvelt, hogy minden kapcsolatot elvágtunk „vissza a természetbe”. Meg kell tennünk ezt a lépést visszafelé, hogy megértsük, hogyan helyezték magukat az emberek a természet középpontjába, és hogy megértsük azokat a fizikai folyamatokat, amelyek a természeten belül folynak. Komolyan kell vennünk a természetet, s ez annyit jelent, hogy a társadalomföldrajzosoknak és politikai ökológusoknak ki kell találniuk, hogyan ,szivárogjanak be a természeti földrajzba”. Válaszában Andrea Nightingale megkérdezte, „Milyen tudást szerzünk a természettől?", és felhívta a figyelmet arra, hogy jobb metodológiai eszközökre van szükségünk, hogy megérthessük a tudás termelésének és megszerzésének ezt a folyamatát. Ha szem elött akarjuk tartani, hogyan lehetséges az ökológiai változások ,egyszerre társadalmi és természeti” mivolta, meg kell határoznunk azokat a geográfiai megközelítéseket és metodológiákat, amelyek inkább elbírják ezt a feszültséget, semmint megerösítik az „emberi” és a „fizikai” között húzódó dichotómiáat.

A jelen beszámoló elkerülhetetlenül sok fontosabb problémát és kérdést hagy ki, amelyek „A természet geográfiái” témakörrel kapcsolatban felvetődtek. Számos, még termékenyebb párbeszéd és eszmecsere zajlott le a panelvitákon belül és kívül is, s készenlétben is maradnak a nemzetközi kritikai geográfia következö kongreszszusára, amelyet 2005 januárjában, Mexikóvárosban rendeznek. Már felbukkantak más témakörök is, amelyeket fel lehet venni a természet geográfiáiról szóló ủjabb szekciósorozatba. Ebben a meglehetősen korai stádiumban Koji Nakashimaval és Marcella Schmidttel elkészítettünk egy egyelöre még átmeneti listát, amely keretbe foglalja a következó találkozónk új és alakulóban lévő kérdéseit:

\section{1) A természet kifejezése mások által}

$\mathrm{Ez}$ a szekció azt mutatja be, hogy a természet társadalmi létrehozásával, a tỏkével vagy egyéb erök által hogyan fejezhetök ki a hatalmi viszonyok, és hogyan tarthatók fenn. A dolgozatok megvizsgálják, hogyan materializálódnak a különbségek a természet geográfiái révén. 
Tények és vélemények a kritikai geográfiáról , a 3. Nemzetközi Kritikai Geográfiai Konferenciáról

Tér és Társadalom 17. évf. 2003/2. 107-110. p.

110 Tények és vélemények a kritikai geográfiáról

TÉT XVII. évf. 2003

2) Identitás és természetépítés

Ez a szekció a természet sajátos, helyi kultúrák általi megteremtését mutatja be, és azt, hogyan támogatja ez a természetépítés a már meglévő csoportidentitást az adott helyen. A vita lehetséges területei: nemzeti parkok, alulról jövő természetvédelmi kezdeményezések vagy helyi, nemzeti diskurzusok a földröl.

3) Helyi küzdelmek a környezetért

Ez a szekció a környezetvédelmi aktivizmus és a természet révén megvalósított identitás felépítése közötti kapcsolatokat vizsgálja. Míg a környezetvédelmet széles körben „globális" mozgalomnak gondolják, több, a környezet megőrzéséért folytatott harc új, világosan körülhatárolható helyekről kiinduló identitásokat teremt. A dolgozatok azt mutatják be, hogyan lépnek kölcsönhatásba ezek az identitások a helyi/globális dinamikával.

4) A természet bennszülött csoportok általi visszavétele

Ez a szekció összehasonlító és kultúrák közötti szemlélettel közelít a természethez; szemügyre veszi létrehozásának különbözó módjait a teljességgel iparosodott és a hagyományos társadalmak közötti széles spektrumban. A dolgozatok a természet „alternatív” megépítését vizsgálják, amely másfajta piacgazdaságot, gazdasági fejlődési utat és társadalmi szervezetet támogat.

5) A természet határokon átívelö magával ragadása

Ez a szekció azt vitatja meg, hogyan nöhet ki egy „haladó” politika a természet megteremtéséből. A dolgozatok különféle társadalmi természetü esettanulmányokat tárgyalnak, amelyek inkább támogatják, mint korlátozzák a felszabadító erejü politikai programokat.

Ezek csak lehetséges módjai a vitának. „A természet geográfiái” témakör szervezői és résztvevői továbbra is közösen kutatják majd ezeket a témákat, és nagy várakozással tekintenek az újabb, mexikói találkozás elé, hogy folytathassák a Vancouverben megkezdett, Taeguban és Békéscsabán tovább vitt munkát.

Fordította: Miskolczy Lászlóné 